\title{
Article \\ Drivers of Spatial Heterogeneity in the Russian Forest Sector: A Multiple Factor Analysis
}

\author{
Roman V. Gordeev ${ }^{1,2, *(\mathbb{D}}$, Anton I. Pyzhev ${ }^{1,2} \mathbb{1}$ and Miron A. Yagolnitser ${ }^{2}$ \\ 1 Laboratory for Climate Change Economics and Ecological Development, Siberian Federal University, \\ 660041 Krasnoyarsk, Russia; apyzhev@sfu-kras.ru \\ 2 Institute of Economics and Industrial Engineering, Siberian Branch, Russian Academy of Sciences, \\ 630090 Novosibirsk, Russia; miron@ieie.nsc.ru \\ * Correspondence: rgordeev@sfu-kras.ru; Tel.: +7-(391)-206-20-85
}

Citation: Gordeev, R.V.; Pyzhev, A.I.; Yagolnitser, M.A. Drivers of Spatial Heterogeneity in the Russian Forest Sector: A Multiple Factor Analysis. Forests 2021, 12, 1635. https:// doi.org/10.3390/f12121635

Academic Editor: Damian C. Adams

Received: 20 October 2021

Accepted: 23 November 2021

Published: 25 November 2021

Publisher's Note: MDPI stays neutral with regard to jurisdictional claims in published maps and institutional affiliations.

Copyright: (c) 2021 by the authors. Licensee MDPI, Basel, Switzerland. This article is an open access article distributed under the terms and conditions of the Creative Commons Attribution (CC BY) license (https:// creativecommons.org/licenses/by/ $4.0 /)$.

\begin{abstract}
This study explored the regional differences in the forest industry and management via a Multiple Factor Analysis approach. The dataset used comprises all Russian regions and 34 variables that comprehensively describe the situation in the sector. Based on the Multiple Factor Analysis, the variables contributing most to the spatial heterogeneity in Russian forestry were divided into industrial and forestry factors. The regions leading in the development of the timber industry are mainly located in the Northwestern and Southeastern parts of Russia. They show similarities in high logging volumes, investment attractiveness, and competitiveness in foreign markets. However, a divergence was found between the Northwestern regions and the Siberian and the Far East territories in terms of forest management factors. The Western part of Russia benefits from the density of the population and infrastructure, and proximity to the national financial centers and European markets. By comparison, Asian Russia suffers from labor shortages caused by negative demographic trends and the negative consequences of climate change, resulting in an increase in forest losses and a lack of control, finance, and transport accessibility due to the vast territory. To alleviate regional inequalities, we propose the introduction of private ownership of forests, support for investment projects, and human capital development.
\end{abstract}

Keywords: forest economics; forest policy; timber industry; multiple factor analysis; principal components; competitiveness; Asian Russia; Siberia; the Russian Far East; regional economics; spatial heterogeneity

\section{Introduction}

The Russian forest sector is of great importance for the global economy in several dimensions, including climate change and carbon storage, biodiversity preservation, water regulation and soil protection, and global ecosystem services, and plays a significant role in timber supply [1,2].

However, there is lack of literature concerning Russian forestry. Bibliometric analysis showed that from 1995 to 2020 only 5-6 articles were published annually, according to the Scopus and Web of Science databases [3]. Moreover, articles focused on regional peculiarities of Russian forestry are even more scarce. Although several studies are devoted to the problems of the forest industry in relation to a particular region [4,5] or a group of regions included in the federal district, especially the Far Eastern and Northwestern regions [6-8], only a few of these analyze the overall national forest sector. A rare example of a productive and substantial study is the recently published work on the impact of climate change on the development of forestry in Russia [2]. The authors covered the state of Russian forestry, possible threats of climate change, and proposed strategies of adaptation and mitigation, including development of the bioeconomy sector.

In previous studies, we analyzed the competitiveness level of forest products in Russian regions using the concept of comparative advantages [9,10]. A strong difference 
between development levels of wood and paper sectors in Russia was found, in addition to spatial heterogeneity. The classification of Russian regions was undertaken in accordance with their revealed comparative advantages. Nevertheless, the obvious fact is that the disproportions in regional trade patterns are only a consequence of the discrepancies in the endowment of general factors, such as forest area, labor, investment conditions and institutional mechanisms. In addition, it was concluded that there is a large amount of statistical data that is still not used in academic research or in policy-making issues [11].

In addition to the level of industrial development, the spatial heterogeneity of the Russian forest sector also appears in several other dimensions. Although more than $90 \%$ of Russia's forests are boreal, there are significant regional differences in species composition that affect the development of the forest industry. Forests in the European part of Russia are mainly dominated by spruce $(34 \%)$, pine $(26 \%)$, and birch $(26 \%)$. In contrast, in the Asian part of Russia, larch is the most representative dominant tree species $(43 \%)$, whereas the share of other species is not as significant: pine (13\%), birch (13\%), cedar (6\%) [12].

After the collapse of the Soviet Union, differences in forest management in the Russian territories amplified significantly [13]. Governmental expenditures on forest management vary greatly among Russian regions. Transaction costs per hectare of forest land range from 0.1 rubles per ha (Republic of Bashkortostan) to 1826 rubles per ha in the Lipetsk Oblast. In addition, transaction costs per ha in Siberia and the Far Eastern export-oriented regions are relatively low compared to the European part of Russia [14].

Consequently, the regional differences have a significant impact on land-use outcomes. Wendland et al. [15] studied the main drivers of timber harvesting in European Russia and found that road density, the percent of evergreen forest, and the total area of forest make the greatest contributions to the diversity of forest disturbance levels in different regions of Russia.

All the aforementioned studies focus on particular sides of spatial heterogeneity in Russian forestry. There has been no attempt to conduct a multidimensional analysis at the regional level. However, filling this gap is necessary to understand the reasons for the success of some regions in the global and Russian forest products markets and the failure of others. Planning of the further development of the timber industry of Russia should be based on the results obtained from the study of the influence of all the main factors characterizing the forest sector.

This study aimed to examine regional heterogeneity in the Russian forest sector by applying data mining methods to official governmental forestry statistics. The main research questions can be formulated as follows: (a) Which factors are the most significant for determining the presence of spatial heterogeneity in the forest sector? (b) Are there any non-obvious relations between different factors? (c) How can the obtained results be applied in the policymaking process?

The article is organized as follows: Section 2 presents a review of the literature on factor analysis methods, a description of the data, and arguments for the choice of the research methodology. Section 3 provides a description of the obtained results. Section 4 discusses the reasons for the spatial heterogeneity in Russia and the path dependence problem in the forest sector of Siberia and the Far East. Section 5 summarizes the main conclusions of the study.

\section{Methods and Data Description}

\subsection{Literature Review}

A common means to identify the most significant variables in a big dataset is to use factor analysis methods. One of the most popular is Principal Component Analysis (PCA). The idea of using the PCA to reduce the dimensionality of the data was first proposed by K. Pearson [16] and H. Hotelling [17]. The method reduces dimensionality by replacing variables. It constructs synthetic uncorrelated indicators (principal components) based on the input variables. In this case, the first principal component (PC1) explains the largest part of the data variation, the second (PC2) slightly less, and so on in descending order [18]. 
Factor analysis is widely used in forestry science. PCA can be used, e.g., to describe variability in wood samples [19], to study tree stem profiles [20], or to select the best predictors for the stem volume [21].

Kolev [22] explored the development level of 35 Bulgarian state forest territories, applying PCA to Pan-European Indicators for Sustainable Forest Management [23]. CoulibalyLingani et al. [24] used PCA to determine the most important factors of local people's participation in the forest management program in Burkina Faso. Another example of applying factor analysis methods to explore the effectiveness of forest management was conducted by Azadi et al. [25]. In both studies, the results were used to make recommendations for changes in forest management policy.

PCA is also a simple and effective method for analyzing overall industry trends. However, there are few studies on the application of this method to forest sector data. Liubachyna et al. [26] used PCA to study characteristics of the forest sector in 21 European countries. The evaluated three principal components represented $70 \%$ of data variation and reflected three groups of indicators: "Socio-Economic Conditions and "Ownership", "Production Value of the Forest Sector", and "Forest Sector Conditions". Kolev et al. [27] used several indicators, such as output, forest area, growing stock, net annual increment, gross fixed capital formation, labor productivity, and net entrepreneurial income, to assess the national forestry competitiveness in the 15 European countries using PCA.

\subsection{Dataset Description}

Although the above-mentioned studies succeeded in explaining a relatively large proportion of the differences between European countries, the number of involved indicators of competitiveness or effectiveness of forest management is not exhaustive. In this paper, we consider a wide range of variables that comprehensively describe the Russian forestry. All indicators were classified into six main groups (Table 1).

Table 1. Indicators of the Russian forestry development.

\begin{tabular}{|c|c|c|c|}
\hline Group & Variables & Description & Mean \\
\hline \multirow{4}{*}{ Stock } & Stock & Wood stock per ha of forest area $\left(\mathrm{m}^{3} / \mathrm{ha}\right)$ & 139.5 \\
\hline & FSC & Share of FSC-certified forested land in the total forest area (\%) & $7.0 \%$ \\
\hline & Forest area & Share of forested land in the total area of the region (\%) & $35.7 \%$ \\
\hline & Reforestation & $\begin{array}{l}\text { The ratio of the area of reforestation and afforestation to the felled } \\
\text { and deadwood area (\%) }\end{array}$ & 123.1 \\
\hline \multirow{3}{*}{ Loss } & Loss & Percentage of deadwood in forested land (\%) & $0.03 \%$ \\
\hline & Fires & Proportion of forest area affected by fires in forested land (\%) & $0.3 \%$ \\
\hline & Pests & $\begin{array}{l}\text { Share of forest area affected by the pest outbreaks in forested land } \\
\qquad(\%)\end{array}$ & $2.2 \%$ \\
\hline \multirow{6}{*}{ Forestry } & Public expenditures & $\begin{array}{l}\text { Factual expenditures on the governmental forest management } \\
\text { activities, from all sources of funding per thousand ha (US\$) }\end{array}$ & 9191.1 \\
\hline & Forestry: Employees & $\begin{array}{l}\text { Share of employment in the forest management sector in the total } \\
\text { labor force }(\%)\end{array}$ & $0.1 \%$ \\
\hline & Forestry: Salary & $\begin{array}{l}\text { Average monthly nominal gross salary in the forest management } \\
\text { sector per employee (US\$) }\end{array}$ & 382.5 \\
\hline & Forestry: Net profit & Net profit in the forest management sector per employee (US\$) & 225.7 \\
\hline & $\begin{array}{l}\text { Forestry: } \\
\text { Profitability }\end{array}$ & Profitability of the cost of sales in the forest management sector (\%) & 15.3 \\
\hline & Forestry: Shipped & $\begin{array}{l}\text { Sales of goods and services by the forest sector per employee } \\
\qquad(1000 \text { US\$) }\end{array}$ & 9.2 \\
\hline
\end{tabular}


Table 1. Cont.

\begin{tabular}{|c|c|c|c|}
\hline Group & Variables & Description & Mean \\
\hline \multirow{8}{*}{ Logging } & Cut: Employees & Share of the logging sector employment in the total labor force $(\%)$ & $0.2 \%$ \\
\hline & Cut: Salary & $\begin{array}{l}\text { Average monthly nominal gross salary in the logging sector per } \\
\text { employee (US\$) }\end{array}$ & 363.7 \\
\hline & Cut: Net profit & Net profit in the logging sector per employee (US\$) & 846.8 \\
\hline & Cut: Profitability & Profitability of the cost of sales in the logging sector (\%) & 7.9 \\
\hline & Cut: Shipped & $\begin{array}{l}\text { Volume of shipments of goods and services in the logging sector } \\
\text { per employee (1000 US\$) }\end{array}$ & 20.3 \\
\hline & Illegal cut & Share of illegal logging in the total wood stock (\%) & $0.001 \%$ \\
\hline & Cut & Share of logging in the total wood stock $(\%)$ & $0.3 \%$ \\
\hline & Wood: Employees & $\begin{array}{l}\text { Share of the wood processing sector employment in the total labor } \\
\text { force }(\%)\end{array}$ & $0.6 \%$ \\
\hline \multirow{5}{*}{ Wood } & Wood: Salary & $\begin{array}{l}\text { Average monthly nominal gross salary in the wood processing } \\
\text { sector per employee (US\$) }\end{array}$ & 384.1 \\
\hline & Wood: Net profit & Net profit in the wood processing sector per employee (US\$) & 692.8 \\
\hline & Wood: Profitability & Profitability of the cost of sales in the wood processing sector $(\%)$ & 5.8 \\
\hline & Wood: Shipped & $\begin{array}{l}\text { Volume of shipments of goods and services in the wood processing } \\
\text { sector per employee (1000 US\$) }\end{array}$ & 34.8 \\
\hline & Wood: RTA & $\begin{array}{c}\text { Revealed trade advantage index calculated for the wood processing } \\
\text { sector }\end{array}$ & 0.9 \\
\hline \multirow{8}{*}{ Paper } & Wood: PIP & $\begin{array}{c}\text { The number of Priority Investment Projects (PIP) for wood } \\
\text { processing in the region (items) }\end{array}$ & 1.7 \\
\hline & Paper: Employees & $\begin{array}{l}\text { Share of the pulp and paper sector employment in the total labor } \\
\text { force }(\%)\end{array}$ & $0.3 \%$ \\
\hline & Paper: Salary & $\begin{array}{l}\text { Average monthly nominal gross salary in the pulp and paper sector } \\
\text { per employee (US\$) }\end{array}$ & 419.5 \\
\hline & Paper: Net profit & Net profit in the pulp and paper sector per employee (US\$) & 5186.4 \\
\hline & Paper: Profitability & Profitability of the cost of sales in the pulp and paper sector $(\%)$ & 9.5 \\
\hline & Paper: Shipped & $\begin{array}{l}\text { Volume of shipments of goods and services in the pulp and paper } \\
\text { sector per employee (1000 US\$) }\end{array}$ & 68.6 \\
\hline & Paper: RTA & $\begin{array}{c}\text { Revealed trade advantage index calculated for the pulp and paper } \\
\text { sector }\end{array}$ & 1.7 \\
\hline & Paper: PIP & $\begin{array}{c}\text { The number of Priority Investment Projects (PIP) in the pulp and } \\
\text { paper industry in the region (items) }\end{array}$ & 0.2 \\
\hline
\end{tabular}

Most of the indicators were recalculated into relative terms per forest hectare or per employee to allow for more accurate comparisons between regions to control for scale. Initially, all monetary indicators were denominated in rubles (RUB). To convert them into the dollar equivalent, we used the annual average nominal dollar to ruble exchange rate (64.73 RUB, in average for 2019, according to the Central Bank of the Russian Federation) [28].

The first group, 'Stock', comprises 4 indicators concerning regional forest reserves in terms of forested land and wood stock. Due to its large territory, Russia has the world's largest forest area but is ranked only fifth in terms of wood removals [29]. The most significant reserves are located in Siberian and Far Eastern regions, particularly in Yakutia, Krasnoyarsk Krai, Irkutsk oblast, and Khabarovsk Krai. However, it is notable that a significant part of these forests is outside of economic use due to their northern location and, consequently, the lack of infrastructure [9]. Another important parameter is the ratio of reforested area to the area of losses. The reforestation and afforestation activities have traditionally been underfunded in Russia for many years [30]. Additionally, we use an indicator of sustainable forest management- the share of the forest area certified by the Forest Stewardship Council (FSC). Forest and supply chain certification is a vital process for forestry development, which provides access to new timber markets and improves relationships between companies and local communities [31]. The area of certified forests in Russia is increasing rapidly and reached $56.4 \mathrm{mln}$ ha in 2020, which is $25 \%$ of the global value. The number of supply chain certificates is not as significant (836 items), which is 
$1.9 \%$ of the global total. Nevertheless, in 2020 , the number of supply chain certifications showed an annual increase of $14 \%$ [32].

The second group, 'Loss', combines 3 parameters revealing the volume of dead forests and the main two non-anthropogenic causes of deforestation. Climatic change stimulates the increase in forest losses by raising the frequency of pest outbreaks [33,34] and forest fires. The biggest forested Russian regions, such as Yakutia and Krasnoyarsk Krai, have suffered significant fires in their northern parts [35-37].

The next four groups unite rather similar business data, divided by the type of the economic activity: forestry sector, logging sector, wood processing sector, and pulp and paper sector. These parameters mainly describe the state of the forest business and the labor market: employees, salary, net profit, profitability of the cost of sales, and volume of shipments. Differences between the groups should be discussed more thoroughly.

The 'Forestry' group contains the factual expenditures on the governmental forest management activities. The high degree of centralization of the authorities in Russia affects the quality of decision-making in the field of forestry [11]. Regions do not have either the credentials or the financial resources to maintain forests. Regional budgets are mostly in deficit, and the federal government allocates subventions for the implementation of delegated powers in the field of forest relations [38].

The 'Logging' group contains two original indicators that cover the shares of legal and illegal logging in the total regional timber stock. The problem of illegal logging is very important for Russia, especially for its Asian territories [39]. Another important issue is that the discrepancies between governmental and non-official estimates of the volumes of illegal cut are very large [39]. In this paper, we use the official data of the Russian Federal Agency Rosleskhoz, because it is the only source covering all the regions.

The 'Wood' and 'Paper' groups also combine two original indicators. The first is the competitiveness index using the idea of revealed comparative advantage [40,41]. Since the first measure proposed by Liesner [42], a large number of comparative advantage indices have been proposed [43-45]. In this study, we use Revealed Trade Advantage index (RTA), proposed by Vollrath [43]. By comparison to the traditional Balassa index [41], it takes into account both export and import flows and excludes double counting of countries and goods:

$$
\mathrm{RTA}_{i j}=\mathrm{RXA}_{i j}-\mathrm{RMA}_{i j} \text {, }
$$

where $\mathrm{RXA}_{i j}$ and $\mathrm{RMA}_{i j}$ are calculated as follows:

$$
\begin{aligned}
& \operatorname{RXA}_{i j}= \frac{\sum_{i j}}{\frac{\sum_{i} X_{i j}-X_{i j}}{\left(\sum_{i} \Sigma_{j} X_{i j}-\sum_{j} X_{i j}\right)-\left(\sum_{i} X_{i j}-X_{i j}\right)}}, \\
& \operatorname{RMA}_{i j}=\frac{\frac{M_{i j}}{\sum_{i} M_{i j}-M_{i j}}}{\frac{\sum_{j} M_{i j}-M_{i j}}{\left(\sum_{i} \sum_{j} M_{i j}-\sum_{j} M_{i j}\right)-\left(\sum_{i} M_{i j}-M_{i j}\right)}} .
\end{aligned}
$$

In previous studies, it was shown how RTA can be used on forestry data at the national [46] and regional scales [9]. In this case, $X_{i j}$ and $M_{i j}$ are the exports and imports of the certain region $j$ for the commodity group $i$. Thus, the region is competitive in trade within a given commodity group if the RTA value is positive, whereas a negative value should be interpreted as revealed comparative disadvantage.

Trade flows in the wood processing sector are comprehensively captured by the code 44 of the Harmonized Commodity Description and Coding System (HS). For the pulp and paper sector we used the sum of the values for 47 and 48 HS codes.

Another indicator, which is presented only in the 'Wood' and 'Paper' groups, is the number of Priority Investment Projects (PIP) in a particular region. This program appeared in 2007 and became the main development driver in the Russian timber sector [47]. Participation in this program provides investors with preferential lease terms for forest 
plots in exchange for the creation or modernization of timber or paper production facilities and forest infrastructure [48]. However, the lack of control over compliance with investors' obligations in a number of cases has caused damage to the ecology of the territories [49]. In this study, we used the number of Priority Investment Projects in the forest industry as an indicator of investment activity in the region.

Mostly, data was obtained from the Unified Interagency Information and Statistical System (EMISS) [50], which is the convenient interface to the data provided by all the federal public authorities in Russia. In addition, we gathered other indicators from other resources. The trade data for calculating RTA was obtained from the Federal Customs Service of Russia (FTS) [51]. Information about FSC certified companies as of January 2020 is available on the website of FSC Russia [52]. The area of the forest fires and the illegal logging volumes were obtained from the official website of the Russian Federal Agency Rosleskhoz [53]. Almost all indicators reflect the situation in Russian forestry as of 2019. The only exception is the list of Priority Investment Projects, which is available on the website of the Ministry of Industry and Trade of Russia as of April 2021 [54].

Reliability and integrity of the above-mentioned data were discussed in [11]. In this study, we employed data for all 85 Russian regions. Although two regions, Nenets Autonomous Okrug and Chukotka Autonomous Okrug, do not conduct economic activity in the forestry sector, they were still included in the analysis because they have forest reserves and suffer from timber losses. There are also four regions with underreported labor statistics that do not correspond with their shipment volumes. Therefore, we recalculated the number of employees in the logging sector for Oryol Oblast and Chechen Republic, the number of employees in the wood processing sector for Kalmykia Republic, and both of those parameters for Magadan Oblast. It should be noted that all 85 regions of Russia are grouped into eight federal districts for the convenience of public administration. To assess the hypothetical number of employees we used the following formula:

$$
E_{r}=\frac{S h_{r}}{\left(\left(S h_{F D}-S h_{r}\right) /\left(E_{F D}-E_{r}\right)\right)},
$$

where $E_{r}$ and $S h_{r}$ represent the number of employees and the volume of shipments in a certain region, whereas $S h_{r}$ and $S h_{F D}$ refer to the same indicators for the federal district. We assume that the territories within one district are sufficiently similar, and therefore the recalculation using Formula (4) will yield a result close to the actual data.

\subsection{Methodology}

The above-mentioned data structure with several groups of indicators stimulates the use more advanced multivariate analysis methods rather than PCA. In this paper, we applied Multiple Factor Analysis (MFA), proposed by B. Escofier and J. Pagès [55]. It is also a principal component method, but is specifically designed for datasets with grouped variables [18]. As a supplementary categorical variable, we added the region's affiliation with one of the federal districts: Central (CFD), Northwestern (NWFD), Southern (SFD), North Caucasian (NCFD), Volga (VFD), Ural (UFD), Siberian (SibFD), Far Eastern (FEFD). All computations and visualizations were done using open-source $\mathrm{R}$ packages FactoMineR [56], factoextra [57], and ggplot2 [58], in the software environment developed by R Core Team [59].

The further stages of the analysis are quite common for studies using principal component methods and can be described as follows:

1. The initial dataset of variables was converted into a new set of uncorrelated principal components (PCs). These principal components are ordered by the level of explained variance in all of the original variables so that the first few PCs retain most of the variation [60].

2. The preliminary analysis on the relationships between all initial factors was conducted by creating the variable correlation plot. On this plot each variable is a point in the 
component space. The coordinates for the variables are given by the correlations between a component and a variable [61].

3. To identify the most important factors in explaining spatial heterogeneity in the Russian forest sector, the contributions of the variables to the first two PCs were calculated.

4. Finally, to detect the possible clusters and outliers among regions the graphical visualization of spatial heterogeneity in Russian forestry was obtained by projecting all observations (regions) in a two-dimensional space. On this plot the axes are represented by the first two PCs, and the coordinates of a particular region are determined by its score for the given PC.

\section{Results}

After undertaking MFA, we obtained the proportion of variances retained by all principal components. The first 10 principal components (PC) explain about $71 \%$ of the differences between regions. For instance, the percentage of explained variance for PC1 is about $19 \%$, for PC2 10.5\%, and for PC3 is equal to $6.6 \%$. Such a distribution of explained variance among PCs is not a convenient result for interpretation. This happens due to a large set of variables, which is quite rare in economic studies, but is a common situation in other fields [62,63].

Linkages between all quantitative indicators and the quality of their representation on the two PCs are shown on the variable correlation plot (Figure 1).

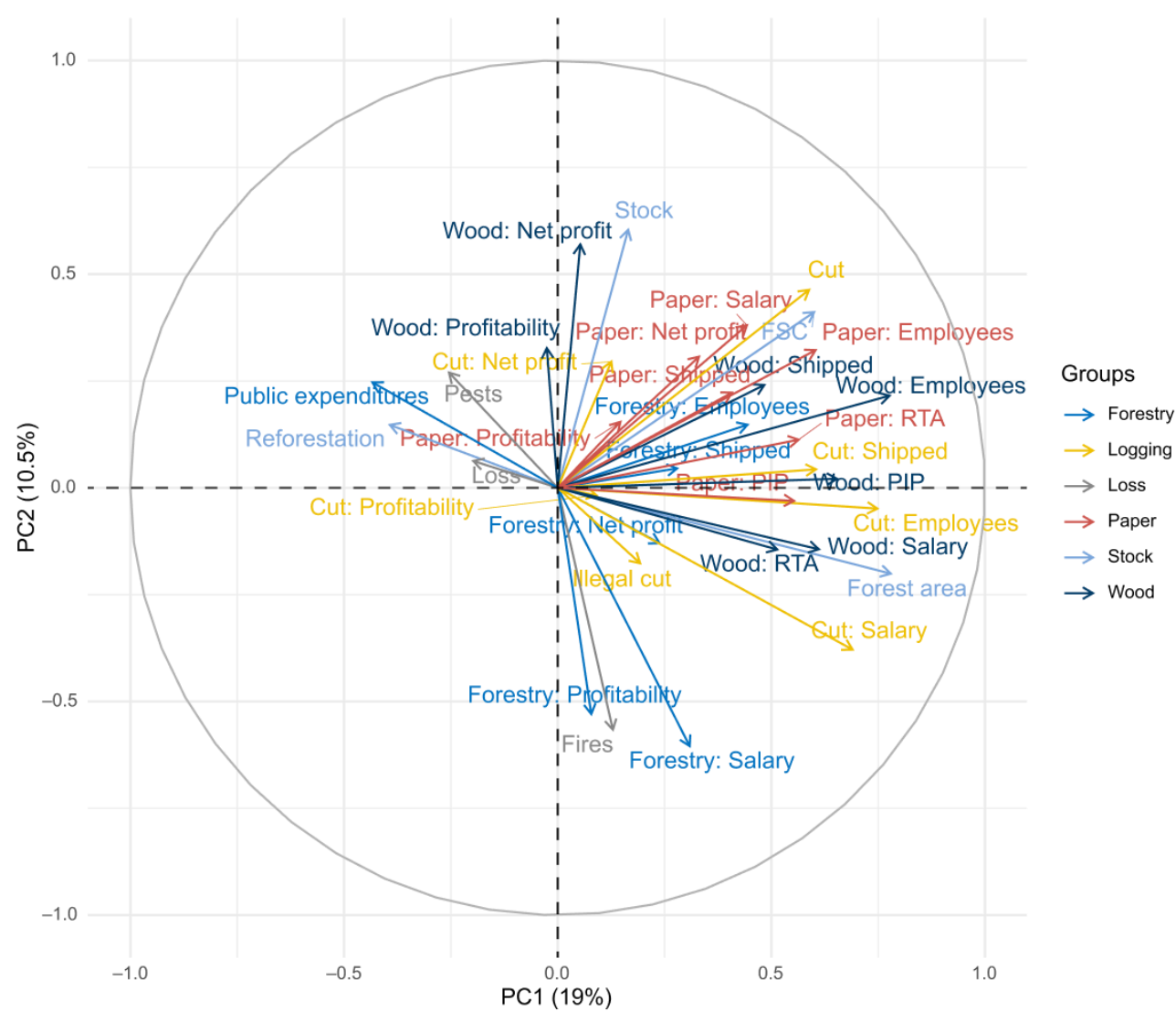

Figure 1. Variable correlation plot. (a) Variables closer to the circle are well explained by the first two components and vice versa; (b) positively correlated variables are grouped together on the same side and vice versa $[18,61]$.

Mostly, variables inside the same groups are positively correlated, as expected. However, there are some linkages that should be discussed more in detail. 
First, for the Logging, Wood, and Paper sectors there is a positive relationship between shipments per employee and salaries. The existence of the link between productivity and wages is still controversial [64]. However, it may be true for the Russian timber sector as the big shipment volumes per employee are provided by the big companies with a higher pay rate. In addition, there is competition for qualified labor in the wood processing sector due to the demographic crisis of the 1990s in Russia [65].

An interesting result is the positive linkage between the share of illegal logging in the total wood stock and the proportion of forest area that has suffered from fires. A possible explanation for this relationship may be that arsons are the usual way of concealing illegal logging. Both of these problems are rather typical for the Asian Russia area.

Several valuable links concerning forest management policy are also found. Public expenditures are negatively related with forest area, FSC, and stock. This suggests that the amount of spending is not becoming proportionately greater for regions with extensive forest reserves, as it should be. Reforestation to loss rate is negatively correlated with almost all variables of the Logging, Wood, and Paper groups. This may indicate that the current level of reforestation is insufficient for regions that intensively harvest and process timber.

The MFA procedure allows the initial variables to be ordered by their contributions in the principal components. The variables that contribute the most to the first two PCs are shown in Figures 2 and 3.

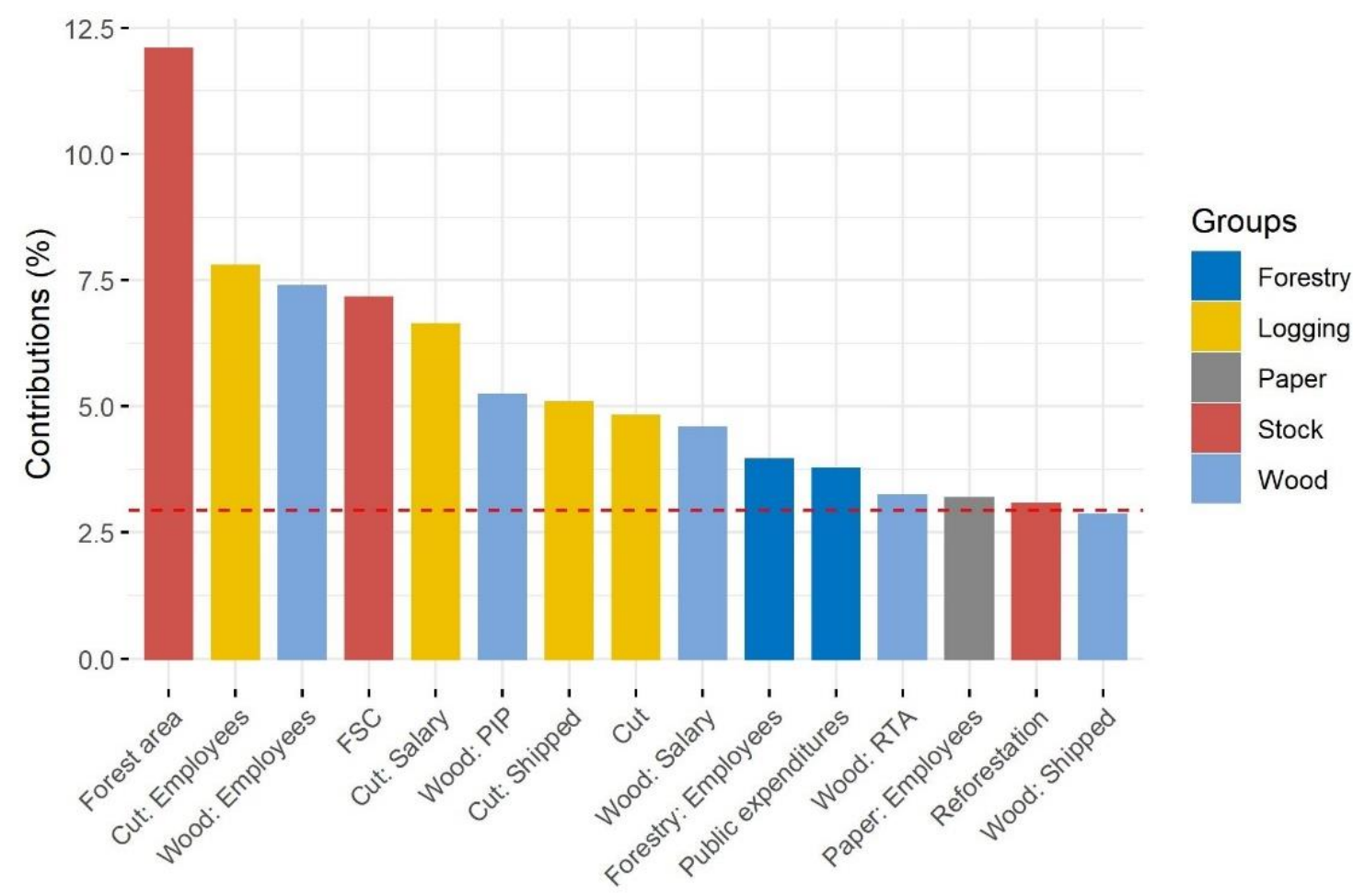

Figure 2. Contribution of the variables to PC1. The red dashed line indicates the expected average contribution level. Variables with higher contributions are more significant in explaining the differences among regions. 


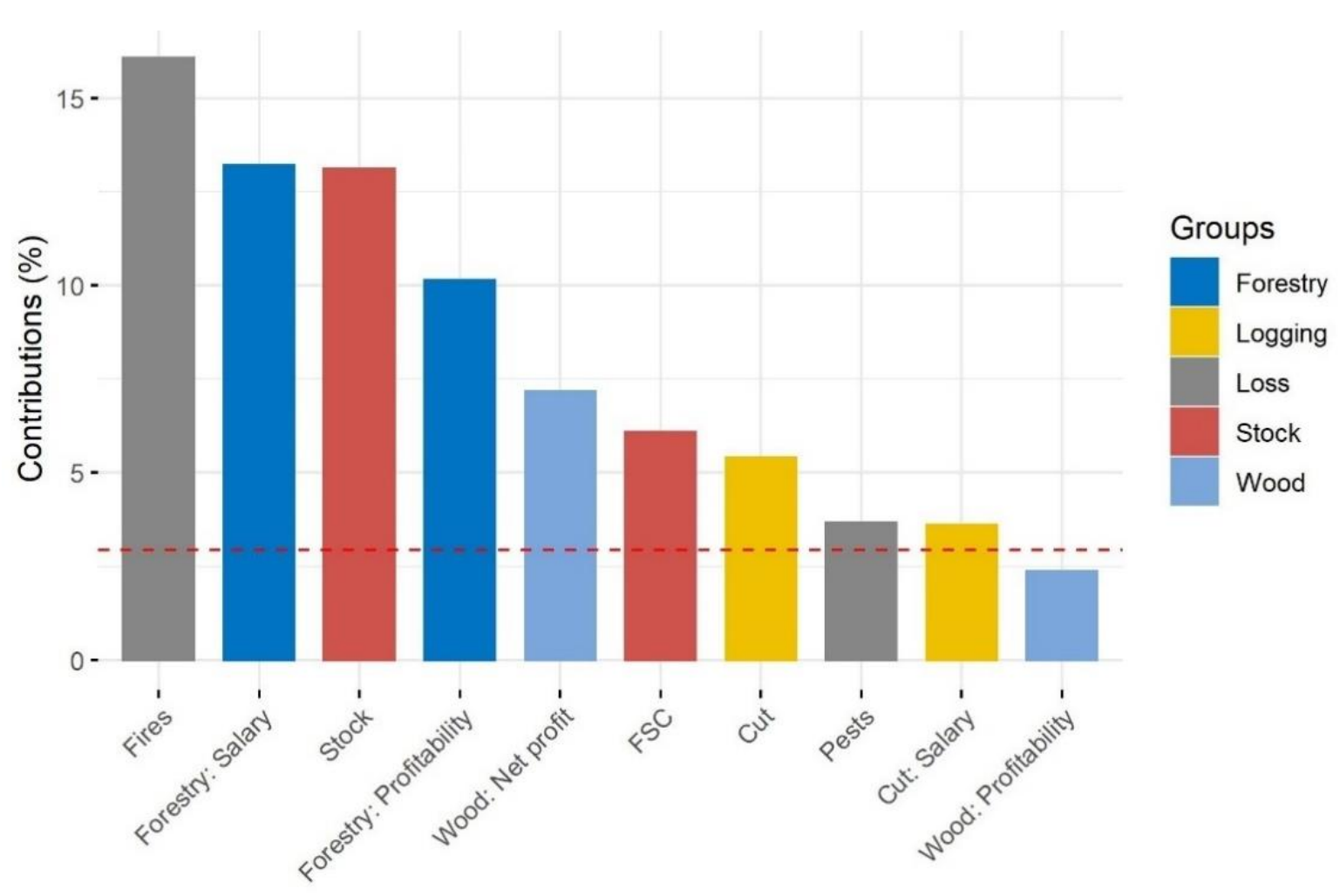

Figure 3. Contribution of the variables to PC2.

Indicators with a contribution level above the red dashed line on the graphs can be considered important for a contribution to a given PC [18]. It means that these variables have the greatest influence on spatial heterogeneity in the Russian forest sector. The largest contributors to PC1 are groups Stock, Wood, and Logging, which are, as expected, related to each other. The share of sectoral employment in the total labor force is significant for all four sectors under study. This indicator can also be seen as the scale and importance of the given sector in the region's economy, which is linked to the forest area, including FSC-certified forests.

The second dimension has the greatest contribution from the Forestry, Stock, and Loss. Except for profits in the wood processing sector, all of the variables describe forest reserves and growth factors in one manner or another. It is notable that the Paper group is not perfectly represented by the first two PCs, which is also true for the other dimensions. With certain assumptions, we can consider PC1 to be representative of timber processing, whereas PC2 is more related to forest management.

The most valuable results from MFA can be obtained by the graph of individuals. Figure 4 represents the Russian regions' performance on the factor map using the first two PCs. All regions are colored by the federal district to which they belong. In addition, regions are scaled by the quality of their representation on the factor map. This indicator is called the squared cosine $\left(\cos ^{2}\right)$ and calculated as the squared coordinates for the certain region. $\operatorname{Cos}^{2}$ measures the degree of association between regions and the certain PC [18]. On Figure 4 we labelled the regions with high values of $\cos ^{2}$ and for the outliers. 


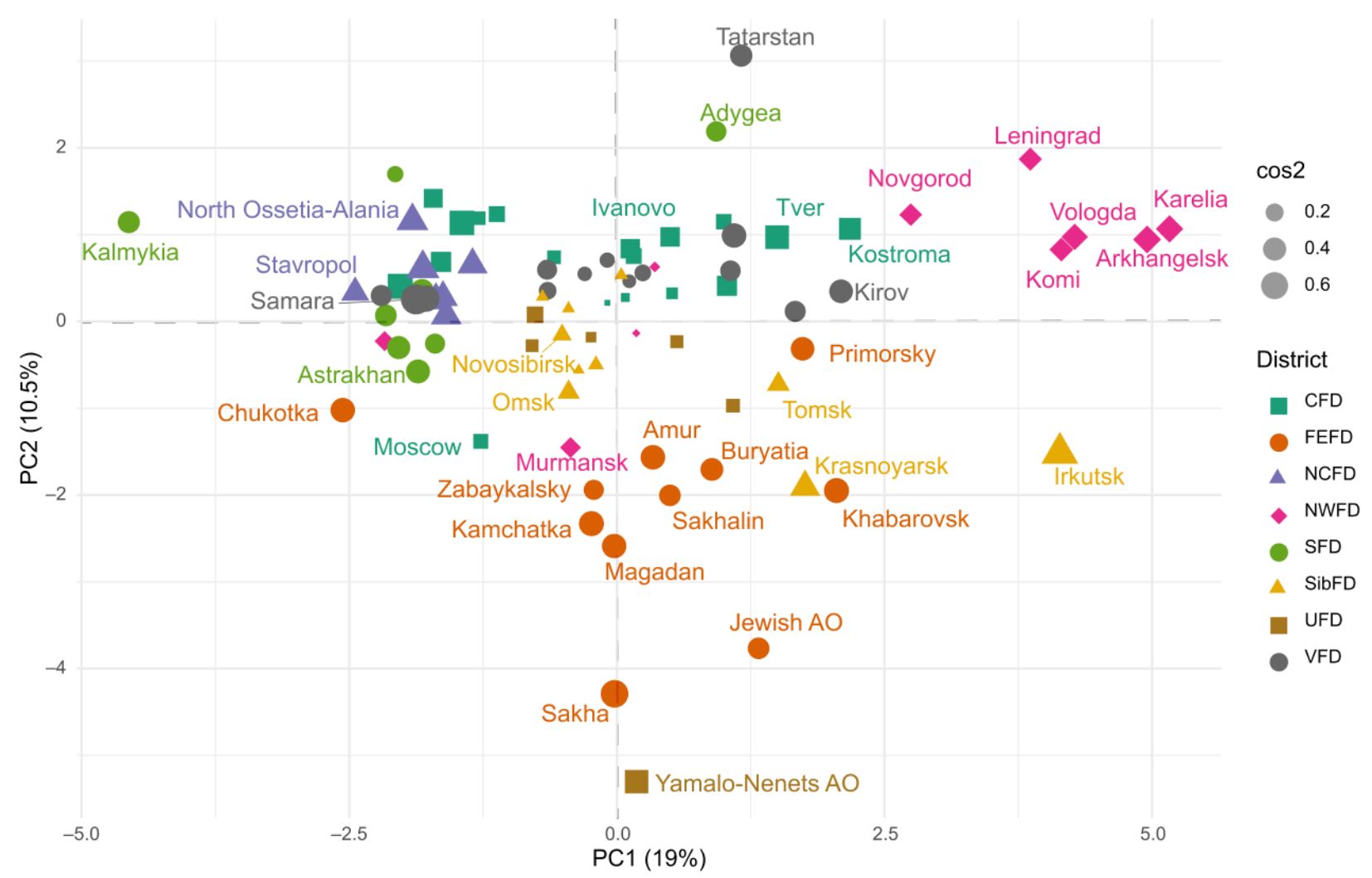

Figure 4. The MFA score plot of the Russian regions.

The obtained factor map reveals some new evidence on the geographical distribution of forestry development in Russia. As was mentioned above, PC1 represents mostly industrial factors, so the first axis mainly opposes the regions with a developed and undeveloped timber industry. The actual sectoral leaders with high values on the abscissa axis belong to several federal districts.

Six regions of the Northwestern federal district (Republic of Karelia, Arkhangelsk Oblast, Vologda Oblast, Komi Republic, Leningrad Oblast, Novgorod Oblast) are close together on the factor map, which indicates they have similar profiles. These regions are acknowledged leaders of the Russian timber industry. They export products with high value added and closely cooperate with the quality-demanding European market. For a few historical reasons, the largest Russian pulp and paper companies, such as JSC 'Mondi Syktyvkar', 'International Paper', and JSC 'Arkhangelsk Pulp and Paper Mill' are also located in the Northwestern regions and provide the entire Russian market with writing paper. The average salary in the Northwest district is $13 \%$ higher in forestry and logging sectors than the same indicator for Russia and is $22-28 \%$ higher in wood and pulp industries. Investment activity in the Northwest is also higher than in the other federal districts. These six regions accommodate 53 Priority Investment Projects, which account for $33 \%$ of the total number, and the Vologda Oblast itself accounts for 21 projects or $13 \%$. In addition, the first Russian timber cluster, PomorInnovaLes, was created in Arkhangelsk Oblast.

Siberian and Far Eastern regions are relatively close to each other. As they are distributed over the two bottom quadrants, these regions can be divided by the development level of the timber industry. Among Siberian regions, Irkutsk Oblast, Krasnoyarsk Krai, and Tomsk Oblast can be considered as the most developed in the wood industry. As was mentioned in Section 2, Irkutsk Oblast and Krasnoyarsk Krai are the national leaders in terms of the wood stock and the cut volumes. In 2019, logging volumes reached $58.6 \mathrm{mln}$ $\mathrm{m}^{3}$ in Irkutsk Oblast and $25.6 \mathrm{mln} \mathrm{m}^{3}$ in Krasnoyarsk Krai, which are $26.8 \%$ and $11.7 \%$, respectively, of the total volume of harvested wood in Russia. A significant proportion 
of the Priority Investment Projects are also implemented in these territories: 15 projects are carried out in the Krasnoyarsk Krai, 11 in the Irkutsk Oblast, and three in the Tomsk Oblast. The other Siberian regions have a less developed forest industry and also are not represented well on the factor map.

Regarding the Far Eastern regions, all of them have relatively high cos 2 values but their location on the factor map is different: Khabarovsk Krai and Primorsky Krai are the largest loggers and exporters of timber products in this macroregion. They are also Far Eastern leaders in terms of the number of forest investment projects. The Republic of Buryatia is the only Far Eastern region that demonstrates comparative advantages in trade in both wood commodities and pulp and paper products due to the Selenginsk Pulp and Cardboard Mill.

The Sakhalin Oblast presents a vivid case of rapid growth of government interest in forestry in the past few years. This is one of seven Russian regions and the only one in the Far East where a 'carbon polygon' will be created. The project of seven pilot carbon polygons is the new governmental program in Russia launched to monitor climatically active gases in certain areas. This project is intended to contribute to the assessment of the carbon balance in Russia. On the opposite side, the Far Eastern regions in the bottom left quadrant of the factor map do not have the possibility of growth due to the lack of infrastructure, especially forest roads.

The North-Caucasian and Southern regions mostly show values below zero on the abscissa axis. This means that they have low values for indicators contributing the most to PC1. Although some of these territories even have comparative advantages in trading a narrow range of goods, the lack of forest resources, landscape peculiarities, and traditional agricultural specialization make these regions 'outsiders' of the forest industry [9]. The most vivid illustration of this situation is in the Republic of Kalmykia. On the contrary, the most successful of these regions is Adygea Republic. Forests cover almost 37\% of Adygea's territory, whereas the average for the Southern federal district is less than $7 \%$. There are also plans to create a timber cluster in Adygea aimed to produce wood furniture, parquet, and other commodities with high value added [66].

Ural regions are not well represented on the factor map and mostly are close to the origin. These regions are also not specialized in forestry. These are mostly industrial regions such as the Chelyabinsk Oblast and resource-producing regions such as the Tyumen Oblast or Khanty-Mansi Autonomous Okrug. The timber industry leader of Ural district is Sverdlovsk Oblast, which has a population of 4.3 million people and $69 \%$ of its territory covered by forests.

The regions of Central and Volga federal districts are distributed relatively evenly over the two quadrants at the top of the Figure 4. Although these districts are not usually seen as the main drivers of national forest industry development, they have a strong position in some indicators. For instance, Volga and Central federal districts are in first and the second places, respectively, in terms of average net profit per worker for the wood industry, and fourth and third places for the same indicator in the logging and paper industries. However, the average salary in the logging, wood, and paper industries in Central and Volga federal districts is lower than that in the Northwestern or Siberian territories, and is a significant restriction of the further development. There are certain forestry leaders such as Kirov Oblast, Perm Krai, and Udmurtia Republic in Volga federal district, and Tver Oblast, Kostroma Oblast, and Vladimir Oblast in Central federal district, which are actively involved in the Priority Investment Projects program.

The second PC mostly represents factors of forest condition, and provides a good illustration of differences in forest management patterns between European and Asian Russia. Siberian and Far Eastern federal districts suffer significantly more from forest fires, pest invasions, and illegal felling, whereas Northwestern and Central areas have developed in a more sustainable way. Several institutional and geographic reasons for this divergence need to be discussed. 
Russian territories located to the West of the Ural Mountains are relatively small and densely populated, making their forests easier to manage, exploit, and protect. An extractive pattern of forest use coupled with comparatively developed infrastructure in the Western part of Russia have already led to a scarcity of wood stock along the existing forest roads. There was an incentive to invest in the construction of infrastructure and intensive reforestation in these areas. In addition, the proximity to the European timber market, with its increasing attention to the origins of exported wood, has substantially stimulated the FSC certification of forests and supply chains.

On the contrary, most of the Siberian and Far Eastern territories are resource abundant but still poor in infrastructure. Their northern areas are sparsely populated and often only accessible by air transport. These conditions make it almost impossible to stop forest fires in such regions as Yakutia or Krasnoyarsk Krai, which cause dramatic damage to forest resources and ecosystems. The vast area of Siberia and the Far East make them more vulnerable to all causes of forest loss. However, Russian boreal forests are very important to the global carbon cycle [67] and need to be protected.

Nevertheless, the governmental expenditures on forest conservation, protection, and reforestation do not correspond to real needs: in 2019 the allotment for pest protection and reforestation in Siberian and Far Eastern Districts was lower than that in the Central Federal district. The expenditures to protect forests from fires in these areas are the highest, but this does not compensate for the high cost of airborne firefighting missions to areas accessible only by air. In relative terms, Siberian and Far Eastern districts rank last in terms of the level of factual expenditures on the governmental forest management activities, from all sources of funding. Although the average for Russian regions in 2019 was USD 91,911 per thousand ha, the mean value for Siberia was USD 17,231 per thousand ha, and the mean value for the Far East equaled USD 12,163 per thousand ha. Yakutia, having a value of USD 1914 per thousand ha, ranked second to last of all regions in terms of this indicator. At the same time, Siberian and Far Eastern federal districts together account for $78.2 \%$ of all forest losses.

Staff shortages are the other problem connected with the growing forest losses in Russia's eastern territories. More than 30\% of all forestry employees in Russia work in the Northwestern federal district. As of 2019, this amounted to 12.5 thousand workers compared with 5.8 thousand in Siberian federal district and 3.9 thousand in the Far East. By comparison, the forested area of Siberia and Far East is 2.5 and 3.8 times greater, respectively, than in the Northwestern federal district.

Finally, there are significant differences in the structure of production and foreign trade. For Siberia and the Far East, especially the cross-border regions, China is the main trading partner, due to its high demand on unprocessed timber. This does not create additional incentives for high value-added production or forests' certification. Moreover, together with the lack of monitoring, it causes an increase in illegal logging volumes.

A few words should be said about the outliers of the PC2 coordinates. Yamalo-Nenets Autonomous Okrug and Sakha (Yakutia) Republic are very close to the second axis and have high negative values for PC2. These are northern territories focused on oil and diamond extraction, respectively. The timber industry is undeveloped in these regions, and they are fully described by forestry indicators contributing mostly to the second dimension. Another interesting example is the Jewish Autonomous Oblast, which is a relatively small region in Russia, but where the wood sector plays an important role in its economy. The share of employment in the wood processing sector in the total workforce is higher than the Russian average, and the region also has a strong comparative advantage in trade in wood products.

On the opposite side, Republic of Tatarstan has high positive coordinates. It is a major economic and financial center of the Volga Federal District, which is one of Russia's most attractive regions for investors. Although only 18\% of Tatarstan is covered with forests, it is the national leader in terms of the percentage of FSC-certified forests, which exceeds 95\%. The supply of wood to the Kastamonu MDF and flooring factory in Elabuga is entirely 
provided by FSC-certified forests. The level of actual costs for the implementation of the transferred federal powers in the field of forest relations is also one of the highest in Russia and equals USD 166,593 per thousand ha.

\section{Discussion}

In this study, we explored spatial heterogeneity in the Russian forest sector using a factor analysis framework. Compared with similar studies on European countries $[26,27]$ we used a broader list of variables describing differences in forestry development between regions. The first two PCs describe about 30\% variation of the whole dataset, which is common for a large number of factors. Although the first component was mainly contributed by timber processing factors, the second was more influenced by factors describing the state of forest resources.

An interesting finding is that results based on MFA are quite similar to the competitiveness estimates obtained through comparative advantage analysis [9]. As Russia is an export-oriented country, it can be concluded that the main patterns of regional timber industry development can be described by the comparative advantage analysis using only trade data. The main industry leaders and significant exporters are localized in northwest Russia and in the cross-border regions of Siberia and the Far East, which is mainly explained by resource abundance and proximity to the large timber markets. By comparison, in the southwestern and northern territories, the timber industry is not developed. For the southern areas this is mainly due to agricultural specialization and a lack of wood stock. The northern regions are characterized by a harsh climate, lack of infrastructure, and specialization in fossil fuels.

However, this manuscript makes a significant contribution to the description of regional forestry in Russia by adding the 'sustainability dimension' to these results. The divergence in the development paths of Western and Eastern Russia was shown in the MFA factor map. We identified several factors that constrain the forestry potential of Siberia and the Far East.

1. Labor market. In contrast to the Western part of Russia, the Siberian and Far Eastern federal districts have low population density (3.90 and 1.17 inhabitants per square kilometer, respectively), distributed mostly along the Trans-Siberian Railway. The steady outflow of the qualified labor force to the Western parts of Russia causes staff shortages. Moreover, salaries in the forestry sector are lower than the average for the economy and do not cover the cost of living in severe climatic conditions and the difficulty of work.

2. Geographic location. The production and trade structure of Siberian and Far Eastern regions depend on Asian demand for low-processed wood products. Another problem is a sparse and poor population that cannot provide a sufficient domestic demand for high value-added products in these areas. In addition, the vast territory makes it unprofitable to deliver products from the Far East to the regions of central Russia. The mixture of these factors makes production of wooden commodities with high value added inherently uncompetitive.

3. Climatic change. The global warming trend is increasing the frequency of fires and pest outbreaks. Combined with a lack of infrastructure, this leads to large losses of boreal forests, which are difficult to recover from. In addition, there is strong evidence of a gradual reduction in logging season durations in Siberia due to climatic change [68].

4. Lack of control. The vast territories with severe climate, low population density, and lack of transport accessibility are hard to control and monitor. Moreover, the contribution of the timber industry to Russian GDP is less than $2 \%$ and the sector is usually not a major focus of policymakers.

5. Lack of governmental expenditures and investments. The forest management sector in Russia is severely underfunded. In Section 3 we show that, in relative terms, the Siberian and Far Eastern federal districts are ranked last in terms of the factual regional costs in the field of forest relations, despite the fact that these territories suffer the 
greatest losses. Furthermore, even money spent on reforestation does not guarantee proper care of seedlings.

6. Quality of statistical data. A detailed assessment of the quality and variety of Russian forest statistical data has shown that despite the large number of indicators present in the databases, some basic indicators of the development of the industry are not reflected [11]. For example, information on the condition of forest roads in Russia is almost absent, which makes it difficult both to assess the current state of the infrastructure and to plan its further development. Observations on most indicators are also limited to 10-15 years, which is too short for most kind of statistical analysis routines. In addition, there are structural changes in the data, e.g., due to the adoption of new classifiers. For this reason, the list of forest industry products observed in different periods of time is highly heterogeneous and not fully comparable. All these problems, together with an underestimation of the impact of fires and the volume of illegal logging, lead to inefficient forest policy.

The combination of these factors is a key to understanding the path dependence problem of timber industry in Russian Eastern territories.

Businesses do not have incentives to produce highly processed products while there is lack of domestic demand and exporting roundwood or sawnwood is much easier and more profitable. In addition, when businesses do plan to implement such projects, there are high infrastructure costs.

The populations of these areas lack entrepreneurial skills, and there is not yet high demand for a sustainable approach to territorial development. The situation has changed during the last ten years, but the effect is not yet substantial [69].

The governmental participation in forestry is highly centralized and places responsibility on regional policy makers, without allocating sufficient resources to them to solve problems. The government is unable to monitor such vast areas, which leads to an increase in forest losses from fires, pests, and illegal cuts. The weak investment attractiveness of the areas and the lack of control leads to any investor being welcomed, resulting in non-compliance with contract requirements and environmental damage [49].

However, there are some positive trends that can be used to improve the situation in the Russian forest sector, especially for Siberia and the Far East. An important shift in the formation of industrial policy in the forestry sector was the Russian President's directive in 2020 to decriminalize the timber industry, which introduced the complete ban on the export of unprocessed timber starting from 2022 [70]. Moreover, since July 2021, export duties have been introduced for certain types of wood. For conifers and oaks, the duty rate has been set at 10\%, but not less than EUR 13 and EUR 15 per cubic meter. Export duties for beech and ash have also been set at 10\%, but not less than EUR 50 per cubic meter.

In addition, since July 2021 it has been mandatory for forest users to provide information to the national information system, LesEGAIS, about the volume of timber, its type and size, and its route of delivery and transport at all stages from harvesting to processing and the customs office. The transactions of forest users for which information is not provided since 2022 transactions will be blocked. Development of the system is being carried out with the involvement of business representatives, for example, Segezha Group [71,72].

Another crucial recent trend is the supply shortage on the world timber market due to the lockdowns caused by COVID-19 [73]. High timber prices provide an opportunity to rethink the current forest policy and to strengthen the positions on the domestic and global markets.

The recent surge in government interest in forestry has led to important changes in the industry that have been desired for many years. Many of the provisions enshrined in official documents, such as Presidential instructions [70] or the Forest Strategy 2030 [74], are indisputably significant for the development of the forestry sector.

One of the possible means of reducing forest losses and increasing the effectiveness of the reforestation process can be to change the forest ownership regime. The econometric analysis shows that there is a weak but positive relationship between the share of private 
ownership of forest land and the growing stock [75]. A new government initiative to allow forestry on abandoned agricultural lands in Russia may be the first step in this direction [76].

While changing wood trade policy it is extremely important to continue to broaden the investment programs, such as Priority Investment Projects and the new program of subsidized loans for small and medium-sized businesses, which was announced to help create value-added wood processing capacities [77]. However, a comprehensive assessment of the possible damage to the industry in terms of job losses and the costs of companies to find new markets and purchase equipment is needed. We believe this is extremely important to prevent negative social and economic effects connected with the sector. State support should be aimed not only at the firms, but also at training and professional development of workers who could take new jobs in the wood processing industry. This is especially important for Siberia and the Far East, which are facing labor shortages.

Last, but not least, the Russian government has a difficult task to find a balance in currency policy between the interests of exporters, which benefit from a cheap ruble, and the population becoming poorer. Essentially, this is an equilibrium between the orientation of the industry toward the foreign market or to domestic demand.

\section{Conclusions}

The main results of this paper can be summarized as follows:

1. Conducting MFA on the dataset of all Russian regions and 34 variables showed the differences in forestry development between Russian regions. This result is consistent with the previous comparative advantage analysis and emphasizes the export-oriented direction of Russian timber industry development.

2. The factors making the largest contributions to spatial heterogeneity in Russian forestry are: wood stock, share of FSC-certified forests, losses from fires and pests, public expenditures in the forestry, employees and salaries, cut volumes, comparative advantages in wood trade, profitability, and net profits of the enterprises. Although the initial dataset gives a good description of Russian forestry, other important indicators were not included in the analysis. For instance, the road density has a significant impact on land-use outcomes [15]. This is particularly true in the comparison of European and Asian territories of Russia. Another important difference between the regions of Russia concerns the structure of harvested tree species. Coniferous timber accounts for $80 \%$ of the logging in Siberia and the Far East. By comparison, in the North-Western Federal District the share of conifers is only $62 \%$, whereas more than $40 \%$ of all Russian hardwoods are harvested in this territory. These differences can have a major impact on the performance of timber companies in the markets and should be studied more thoroughly in future research.

3. A positive linkage was found between the share of illegal logging in the total wood stock and the proportion of forest area affected by fires. Furthermore, the volume of public expenditures is negatively related with the regional forested area and wood stock. This emphasizes the underfunding of the forest management activities in the vast territories of Siberia and the Far East, which suffer from deforestation more than other Russian regions. This pattern leads to negative consequences such as increased $\mathrm{CO}_{2}$ emissions, and severe damage to undisturbed forests and ecosystems.

4. The leaders of the timber industry in Russia are mostly located at the Northwestern, Siberian and Far Eastern federal districts. The North-Caucasian and Southern regions do not participate actively in timber production and trade, whereas Central, Volga and Ural regions are distributed relatively evenly on the factor map.

5. The Western and Eastern regions of Russia are opposed to each other in terms of the effectiveness and sustainability of forestry and forest management. The success of the Northwestern regions is due to several historical and geographical reasons, including foreign investments, closeness to Moscow and Saint-Petersburg as the most powerful financial and economical centers, productive connections with the EU 
market leaders, and a dense road network compared to the Asian part of Russia,. On the contrary, there are many factors that create the path dependence problem that limits the future development of Siberia and the Far East, including the labor market, geographic location, climatic change, lack of control, insufficient forestry funding, and poor quality of available forestry statistics.

6. In our opinion, the future drivers of forestry development in Russia should involve the government support of investment projects, including small enterprises and professional development programs for the employees. Establishment of the private forest ownership mechanism for some pilot areas can also be considered. More than $75 \mathrm{mln}$ ha of abandoned agricultural lands could be used for forestry purposes. This possibility is now being widely discussed by the scientific community and policymakers. Approval of this initiative would exempt farmland owners from fines for illegal afforestation, in addition to enhancing the climate-regulating functions of the forest in the area. In the territories of Siberia and the Far East, more attention should be paid to measures to prevent fires because most occur near populated areas.

\begin{abstract}
Author Contributions: Conceptualization, M.A.Y. and A.I.P.; methodology, R.V.G. and M.A.Y.; software, R.V.G. and A.I.P.; formal analysis, R.V.G.; writing (original draft preparation), R.V.G.; writing (review and editing), R.V.G. and A.I.P.; visualization, R.V.G. and A.I.P.; supervision, A.I.P.; project administration, A.I.P.; funding acquisition, A.I.P. All authors have read and agreed to the published version of the manuscript.

Funding: This research was funded by the Ministry of Science and Higher Education of the Russian Federation within the framework of grant for large scientific projects in priority directions of scientific and technological development no. 075-15-2020-804/13.1902.21.0016 dated 2 October 2020 entitled "Socioeconomic development of Asian Russia based on the synergy of transport accessibility, system knowledge about natural resource potential, expanding space of inter-regional interactions".
\end{abstract}

Data Availability Statement: The study does not report any data.

Conflicts of Interest: The authors declare no conflict of interest.

\title{
References
}

1. Schepaschenko, D.; Moltchanova, E.; Fedorov, S.; Karminov, V.; Ontikov, P.; Santoro, M.; See, L.; Kositsyn, V.; Shvidenko, A.; Romanovskaya, A.; et al. Russian forest sequesters substantially more carbon than previously reported. Sci. Rep. 2021, 11, 12825. [CrossRef] [PubMed]

2. Leskinen, P.; Lindner, M.; Verkerk, P.J.; Nabuurs, G.J.; Van Brusselen, J.; Kulikova, E.; Hassegawa, M.; Lerink, B. (Eds.) Russian Forests and Climate Change. In What Science Can Tell Us; European Forest Institute: Joensuu, Finland, 2020.

3. Pyzhev, A.I. Studies on the Russian forest industry: Bibliometric analysis. Terra Econ. 2021, 19, 63-77. [CrossRef]

4. Chernykh, V. Features and Problems of the Forestry Sector Development in the Republic of Mari El. Stud. Russ. Econ. Dev. 2019, 30, 467-473. [CrossRef]

5. Kharionovskaya, I.V. Forest Resources Assessment as an Element of Sustainable Forestry in the Komi Republic. Reg. Res. Russ. 2021, 11, 129-137. [CrossRef]

6. Antonova, N. Forest Complex of the Far East: Is there Groundwork for Future Development? ECO 2019, 5, 27-47. (In Russian) [CrossRef]

7. Glazyrina, I.P.; Yakovleva, K.A.; Zhadina, K.A. Social and economic effectiveness of the Forest use in the Russian regions. Regionalistica 2015, 2, 18-33. (In Russian) [CrossRef]

8. Trishkin, M.; Lopatin, E.; Karjalainen, T. Exploratory Assessment of a Company's Due Diligence System against the EU Timber Regulation: A Case Study from Northwestern Russia. Forests 2015, 6, 1380-1396. [CrossRef]

9. Gordeev, R. Comparative advantages of Russian forest products on the global market. For. Policy Econ. 2020, 119, 102286. [CrossRef]

10. Gordeev, R. Competitiveness of Forest Sector Products: Lessons from an Analysis of External Trade. Probl. Econ. Transit. 2020, 62, 44-60. [CrossRef]

11. Pyzhev, A.; Gordeev, R.; Vaganov, E. Reliability and Integrity of Forest Sector Statistics-A Major Constraint to Effective Forest Policy in Russia. Sustainability 2020, 13, 86. [CrossRef]

12. Shvidenko, A.; Schepaschenko, D. Carbon budget of Russian forests. Sib. J. For. Sci. 2014, 1, 69-92. (In Russian)

13. Eikeland, S.; Eythorsson, E.; Ivanova, L. From Management to Mediation: Local Forestry Management and the Forestry Crisis in Post-Socialist Russia. Environ. Manag. 2004, 33, 285-293. [CrossRef] 
14. Glazyrina, I.; Zabelina, I.; Faleychik, L. Spatial Heterogeneity of «Green» Economy and Transaction Costs in Forestry. IOP Conf. Ser. Mater. Sci. Eng. 2020, 753. [CrossRef]

15. Wendland, K.J.; Lewis, D.; Alix-Garcia, J.; Ozdogan, M.; Baumann, M.; Radeloff, V.C. Regional- and district-level drivers of timber harvesting in European Russia after the collapse of the Soviet Union. Glob. Environ. Chang. 2011, 21, 1290-1300. [CrossRef]

16. Pearson, K. LIII. On lines and planes of closest fit to systems of points in space. Lond. Edinb. Dublin Philos. Mag. J. Sci. 1901, 2, 559-572. [CrossRef]

17. Hotelling, H. Analysis of a complex of statistical variables into principal components. J. Educ. Psychol. 1933, $24,417-441$. [CrossRef]

18. Kassambara, M.A. Practical Guide to Principal Component Methods in R (Multivariate Analysis), 1st ed.; CreateSpace Independent Publishing Platform: CA, USA, 2017; Volume 2, Available online: https:/ /www.datanovia.com/en/wp-content/uploads/dntutorials/book-preview/principal-component-methods-in-r-preview.pdf (accessed on 20 October 2021).

19. Davidson, J. Use of principal components, factor analysis and varimax rotation to describe variability in wood of Eucalyptus deglupta blume. Wood Sci. Technol. 1975, 9, 275-291. [CrossRef]

20. Real, P.L.; Moore, J.A.; Newberry, J.D. Principal components analysis of tree stem profiles. Can. J. For. Res. 1989, 19, 1538-1542. [CrossRef]

21. Silva, C.A.; Klauberg, C.; Hudak, A.T.; Vierling, L.A.; Liesenberg, V.; Carvalho, S.; Rodriguez, L.C. A principal component approach for predicting the stem volume in Eucalyptus plantations in Brazil using airborne LiDAR data. Forestry 2016, 89, 422-433. [CrossRef]

22. Kolev, K. Factor Analysis of State Forest Territories Sustainable Development in Bulgaria. Innov. Modeling Anal. ICS J. Res. 2020, 5, 9-22.

23. Forest Europe. Madrid Ministerial Declaration 25 years together promoting Sustainable Forest Management in Europe. In Proceedings of the 7th Ministerial Conference on the Protection of Forests in Europe, Madrid, Spain, 20-21 October 2015.

24. Coulibaly-Lingani, P.; Savadogo, P.; Tigabu, M.; Oden, P.-C. Factors influencing people's participation in the forest management program in Burkina Faso, West Africa. For. Policy Econ. 2011, 13, 292-302. [CrossRef]

25. Azadi, H.; Samari, D.; Zarafshani, K.; Hosseininia, G.; Witlox, F. Sustainable forest management in Iran: A factor analysis. Sustain. Sci. 2012, 8, 543-551. [CrossRef]

26. Liubachyna, A.; Bubbico, A.; Secco, L.; Pettenella, D. Management Goals and Performance: Clustering State Forest Management Organizations in Europe with Multivariate Statistics. Forests 2017, 8, 504. [CrossRef]

27. Kolev, K.; Tsoklinova, M.; Delkov, A. Factor analysis of forestry competitiveness. For. Sci. 2020, 2, $143-164$.

28. The Central Bank of Russian Federation. Available online: https:/ / cbr.ru/eng/ (accessed on 23 September 2021).

29. FAO. Global Forest Resources Assessment 2020: Main Report; FAO: Rome, Italy, 2020.

30. Ulybina, O. Russian forests: The path of reform. For. Policy Econ. 2014, 38, 143-150. [CrossRef]

31. Dobrynin, D.; Smirennikova, E.; Mustalahti, I. Non-state forest governance and 'Responsibilization': The prospects for FPIC under FSC certification in Northwest Russia. For. Policy Econ. 2020, 115, 102142. [CrossRef]

32. Forest Stewardship Council Russia The results of 2020. Available online: https://ru.fsc.org/ru-ru/news/id/1158 (accessed on 23 September 2021).

33. Ivantsova, E.D.; Pyzhev, A.I.; Zander, E.V. Economic Consequences of Insect Pests Outbreaks in Boreal Forests: A Literature Review. J. Sib. Fed. Univ. Humanit. Soc. Sci. 2019, 12, 627-642. [CrossRef]

34. Mezei, P.; Potterf, M.; Škvarenina, J.; Rasmussen, J.G.; Jakuš, R. Potential Solar Radiation as a Driver for Bark Beetle Infestation on a Landscape Scale. Forests 2019, 10, 604. [CrossRef]

35. Kotel'Nikov, R.V.; Lupyan, E.A.; Bartalev, S.A.; Ershov, D.V. Space Monitoring of Forest Fires: History of the Creation and Development of ISDM-Rosleskhoz. Contemp. Probl. Ecol. 2020, 13, 795-802. [CrossRef]

36. Loupian, E.A.; Bartalev, S.A.; Balashov, I.V.; Egorov, V.A.; Ershov, D.V.; Kobets, D.A.; Senko, K.S.; Stytsenko, F.V.; Sychugov, I.G Satellite monitoring of forest fires in the 21st century in the territory of the Russian Federation (facts and figures based on active fires detection). Sovrem. Probl. Distantsionnogo Zondirovaniya Zemli Iz Kosm. 2017, 14, 158-175. [CrossRef]

37. Loupian, E.A.; Balashov, I.V.; Bartalev, S.A.; Bourtsev, M.A.; Dmitriev, V.V.; Senko, K.S.; Krasheninnikova, Y.S. Forest fires in Russia: Specifics of the 2019 fire season. Sovrem. Probl. Distantsionnogo Zondirovaniya Zemli Iz Kosm. 2019, 16, 356-363. [CrossRef]

38. Zubarevich, N. Regional and Local Government. In Russia: Strategy, Policy and Administration; Studin, I., Ed.; Palgrave Macmillan: London, UK, 2018; pp. 367-380. ISBN 9781137566706.

39. Center of Forest Ecology and Productivity of the Russian Academy of Sciences. Analytical Note "State of Protection of Forests from Illegal Logging". 2019. (In Russian). Available online: https://efi.int/sites/default/files/files/publication-bank/2021/efi_wsctu_ 11_2021_ru.pdf (accessed on 20 October 2021).

40. Ricardo, D. The Principles of Political Economy \& Taxation; J.M. Dent \& Sons, Ltd.: London, UK; E.P. Dutton \& Co.: New York, NY, USA, 1917.

41. Balassa, B. Trade Liberalisation and "Revealed" Comparative Advantage. Manch. Sch. 1965, 33, 99-123. [CrossRef]

42. Liesner, H.H. The European Common Market and British Industry. Econ. J. 1958, 68, 302. [CrossRef]

43. Vollrath, T.L. A theoretical evaluation of alternative trade intensity measures of revealed comparative advantage. Rev. World Econ. 1991, 127, 265-280. [CrossRef] 
44. Laursen, K. Revealed comparative advantage and the alternatives as measures of international specialization. Eurasian Bus. Rev. 2015, 5, 99-115. [CrossRef]

45. Gnidchenko, A.A.; Salnikov, V.A. Net Comparative Advantage Index: Overcoming the Drawbacks of the Existing Indices, Higher School of Economics Research, Paper No. WP BRP 119/EC/2015, December 2015. Available online: https:/ / econpapers.repec. org/paper/higwpaper/119_2fec_2f2015.htm (accessed on 20 October 2021).

46. Bojnec, S.; Ferto, I. Forestry industry trade by degree of wood processing in the enlarged European Union countries. For. Policy Econ. 2014, 40, 31-39. [CrossRef]

47. Lapo, V. Regions' Competition for Investment Projects in Forest Development. Spat. Econ. 2014, 2, 75-92. [CrossRef]

48. Ivantsova, E.D. Success Factors of the Implementation of State Measures of Investments Stimulation in Russian Timber Industry. IOP Conf. Ser. Earth Environ. Sci. 2021, 666. [CrossRef]

49. Glazyrina, I.P.; Zabelina, I.A.; Klevakina, E.A. An environmental component of economic development: The border regions of Russia and China. EKO 2014, 6, 5-24. (In Russian) [CrossRef]

50. Federal State Statistics Service of Russia Edinaya Mezhvedomstvennaya Informatsionno-Spravochnaya Systema EMISS. Unified Interagency Information and Statistical System. State Statistics. Available online: https://www.fedstat.ru/ (accessed on 23 September 2021).

51. Federal Customs Service. Available online: https:/ / eng.customs.gov.ru/ (accessed on 23 September 2021).

52. Forest Stewardship Council Russia FSC-certified Companies. Available online: https://ru.fsc.org/ru-ru/cert/fsc_companii (accessed on 23 September 2021).

53. Russian Federal Agency Rosleskhoz. Available online: https://test-site.rosleshoz.ru/opendata (accessed on 23 September 2021).

54. Ministry of Industry and Trade of Russia. List of Priority Investment Projects in the Field of Forest Development. Available online: https:/ / minpromtorg.gov.ru/docs / (accessed on 23 September 2021).

55. Escofier, B.; Pagès, J. Analyses Factorielles Simples et Multiples: Objectifs, Méthodes et Interprétation; Dunod: Paris, France, 2008; ISBN 9782100519323.

56. Lê, S.; Josse, J.; Husson, F. FactoMineR: AnRPackage for Multivariate Analysis. J. Stat. Softw. 2008, 25, 1-18. [CrossRef]

57. Kassambara, A.; Mundt, F. factoextra: Extract and Visualize the Results of Multivariate Data Analyses. Available online: https: / / rpkgs.datanovia.com/factoextra/index.html\#factoextra-extract-and-visualize-the-results-of-multivariate-data-analyses (accessed on 23 September 2021).

58. Wickham, H.; Grolemund, G. R for Data Science: Import, Tidy, Transform, Visualize, and Model. Data, 1st ed.; O’Reilly Media: Sebastopol, CA, USA, 2016; ISBN 978-1-4919-1039-9.

59. R Core Team. R: A Language and Environment for Statistical Computing; R Foundation for Statistical Computing: Vienna, Austria, 2020; Available online: https:/ / www.R-project.org/ (accessed on 26 May 2021).

60. Jolliffe, I. Principal Component Analysis, 2nd ed.; Springer: New York, NY, USA, 2002.

61. Abdi, H.; Williams, L.J. Principal component analysis. Wiley Interdiscip. Rev. Comput. Stat. 2010, 2, 433-459. [CrossRef]

62. Bertolini, F.; Galimberti, G.; Calò, D.; Schiavo, G.; Matassino, D.; Fontanesi, L. Combined use of principal component analysis and random forests identify population-informative single nucleotide polymorphisms: Application in cattle breeds. J. Anim. Breed. Genet. 2015, 132, 346-356. [CrossRef] [PubMed]

63. Wang, B.; Jiang, L. Principal Component Analysis Applications in COVID-19 Genome Sequence Studies. Cogn. Comput. 2021, 1-12. [CrossRef] [PubMed]

64. Strain, M.R. The Link between wages and productivity is strong. In Expanding Economic Opportunity for More Americans; Kearney, M.S., Ganz, A., Eds.; The Aspen Institute: Washington, DC, USA, 2019; pp. 168-179.

65. HeadHunter Supply and Demand in the Forest Industry Labor Market in 2019. Available online: https://hh.ru/article/26118 (accessed on 23 September 2021).

66. TASS In Adygea Completed the Registration of Forestry Fund for the Creation of a Timber Cluster. Available online: https: // tass.ru/obschestvo/ 6130534 (accessed on 23 September 2021).

67. Gauthier, S.; Bernier, P.; Kuuluvainen, T.; Shvidenko, A.Z.; Schepaschenko, D.G. Boreal forest health and global change. Science 2015, 349, 819-822. [CrossRef]

68. Chugunkova, A.V.; Pyzhev, A.I. Impacts of Global Climate Change on Duration of Logging Season in Siberian Boreal Forests. Forests 2020, 11, 756. [CrossRef]

69. Pyzhev, A.I.; Sharafutdinov, R.A.; Zander, E.V. Environmental Consequences of Economic Development of Large Industrial Cities in Resource Regions (A Case Study of Krasnoyarsk, Russia). ECO 2021, 7, 40-55. (In Russian) [CrossRef]

70. List of Instructions Based on the Results of the Meeting on the Development and Decriminalization of the Forestry Complex. Available online: http:/ / www.kremlin.ru/acts/assignments/orders/64379 (accessed on 23 September 2021).

71. The State Automated Information System of Wood Accounting Forest LesEGAIS Will Be Extended to All Transactions with Wood and Forest Products, and Its Use Will Be Mandatory for All Market Participants. Available online: https://whatwood.ru/english/the-state-automated-information-system-of-wood-accounting-forest-lesegais-willbe-extended-to-all-transactions-with-wood-and-forest-products-and-its-use-will-be-mandatory-for-all-market-participants / (accessed on 23 September 2021).

72. Alekseev, A.; Tomppo, E.; McRoberts, R.E.; Von Gadow, K. A constructive review of the State Forest Inventory in the Russian Federation. For. Ecosyst. 2019, 6, 9. [CrossRef] 
73. Wunder, S.; Kaimowitz, D.; Jensen, S.; Feder, S. Coronavirus, macroeconomy, and forests: What likely impacts? For. Policy Econ. 2021, 131, 102536. [CrossRef]

74. The Government of the Russian Federation. The Decree Dated September 20, 2018 under no. 1989-p on The Strategy of Development of The Forest Complex Until 2030; Moscow, Russia, 2018. Available online: http:/ / static.government.ru/media/files/cA4eYSe0 MObgNpm5hSavTdIxID77KCTL.pdf (accessed on 20 November 2021).

75. Pyzhev, A.I. Siberian Federal University Siberian Federal University Impact of the Ownership Regime on Forest Use Efficiency: Cross-Country Analysis. J. Inst. Stud. 2019, 11, 182-193. [CrossRef]

76. WWF Asked the Ministry of Natural Resources Not to Deprive the Russians of the Opportunity to Grow Forest on Agricultural Lands. Available online: https://wwf.ru/en/resources/news/lesa/wwf-poprosil-minprirody-ne-lishat-rossiyan-vozmozhnostivyrashchivat-les-na-selkhozzemlyakh/ (accessed on 23 September 2021).

77. Russia Is Launching Subsidized Lending for Wood Processing. Available online: https://whatwood.ru/english/russia-islaunching-subsidized-lending-for-wood-processing/ (accessed on 23 September 2021). 